\title{
Study on Massive Open Online Course and College English Teaching Reform
}

\author{
XU Li-mei, TONG Li-jun \\ Changchun University, Changchun, China
}

\begin{abstract}
English is the universal language. With the development of economic and cultural globalization, the demand for English has gradually increased. Traditional college English teaching cannot meet real requirement, so college English teaching reform is imperative. With the development of online platform, the Internet has brought a great impetus to the curriculum reform. The author thinks that "MOOC" and College English Teaching Reform have a good point of combining, but there is still a problem remaining to be solved: How to make good use of "MOOC" for College English Teaching Reform service has a lot study space in the future.
\end{abstract}

Keywords: MOOC, College English Teaching Reform, combination

\section{Introduction}

MOOC is a means of education that is developed by the leading teachers' and many learners participate in it, which includes teaching video, after-class exercises, network interaction, and learning test. The arrival of the era of MOOC is indeed a revolution in education ideas and ways of education; it also greatly affects the College English Teaching Reform, so colleges and universities need to make full use of the advanced MOOC and promote English teaching reform. This paper combs the relationship between "MOOC" and College English Teaching Reform, explores from a number of perspectives, and makes a deeper reform of the English teaching.

\section{An Overview of MOOC}

MOOC is the abbreviation of Massive Open Online Course, which refers to a kind of new curriculum model in the field of education. MOOC is firstly proposed by Dave Cormier and Bryan Alexander in 2008. It is intended to break the limitation of the traditional education's restriction by time, space, and person through the platform of network. Based on the idea of "open education", MOOC realizes the goal of sharing education resources in the widest range by making a complete design of the curriculum. Then MOOC was paid attention by various famous universities and scholars, among whom Professor Jim Groom (University of Mary Washington) and Professor Michael Branson Smith (City University of New York at York College) both made their own online curriculum opening to the worldwide university and college students which made a big success.

In 2011, there are 16 million people from more than 190 countries who have registered the "Introduction to

XU Li-mei, lecturer, master, Foreign Languages College, Changchun University.

TONG Li-jun, associate professor, master, Foreign Languages College, Changchun University. 
artificial intelligence" of the University of Stanford, which made a big breakthrough in the spread of its fame in the whole world. Then the emergency of three major MOOC operating platforms, namely Udacity massive open online course platform, and Coursera pushes forward the application of MOOC widely. Since 2013, MOOC has been applied in Tsinghua University, Shanghai Transportation University, Fudan University, and other domestic first-class university, which led the "MOOC trend" in our country and played an important role in promoting the development of open education in our country.

\section{The Opportunity That MOOC Brings to College English Teaching Reform}

\section{High Quality Teaching Resources Have Greatly Enriched the College English Teaching}

With the development of MOOC, it can provide us a means and way of relieving the problems, such as: unjust distribution of education resources, course content obsolete, teaching method backward and students lack of innovation and creativity, and so on. MOOC integrates many network tools and digital resources, forms the humanized and diversified learning tools, and rich curriculum resources. It also develops the channel of teaching and learning, updates teaching and learning content in real time, enhances the openness and flexibility of English teaching, and creates an English learning atmosphere that is closer to an English-speaking country.

MOOC provides the science and technology, culture, social life, history, geography, human and nature, etc. Teaching material, highlights the richness and humanities colour of English lesson, makes teaching content more close to the students, closes to the social life, becomes more authentic and practical. The application of MOOC teaching mode, greatly stimulates the enthusiasm of students, cultivates students' interest in learning English, improves the practical application of English skills, cultivates a sense of English using accomplishment, further stimulates students' learning desire, and change students' learning attitude.

\section{Flip the Classroom and Change the Traditional Mode of English Teaching}

In the environment of MOOC, college changed the English teaching strategy; it is a challenge to English teacher, offering a significant opportunity as well. College English teachers should flip themselves, change the concept, realize that teachers are no longer the only source of knowledge authority, change teaching idea, and improve the ability of foreign language teaching, curriculum design, and teaching management ability, advancing with the times. College English teaching is becoming colourful.

MOOC flip-classroom is a kind of "students' autonomous learning-find problem - teacher guides to solve the problem" teaching mode. MOOC emphasizing "learning" has a fundamental hit on the current "teach" teaching mode and influences the absolute right of teachers in teaching activities. Facing the characteristics of the MOOC resources internationalization, college English teachers should play the role of consolidator, guide the student to select the appropriate shared resources, timely supervise and evaluate students' study, and not only guarantee the improvement of students' language ability, but also ensure their own development direction.

\section{Solve the Problem of English Stratification Teaching, Meet the Talent Training Needs}

The related data of millions of students' online learning will be collected into a "big learning data", and based on the background of cloud computing, internet of things, large data, and other integrated technology's MOOC, teachers can use the platform to produce vast amounts of learning resources, sustainably improve the 
design of teaching content and teaching links, and implement personalized learning service of "teaching students in accordance with their aptitude".

At the same time, through systematic data, the teacher can understand the status of the students' learning at any time, such as: find learners individual law of real learning and learning behaviour, monitor, track, and record the trajectory of learning. Through analyzing these data, teacher can make model for every student, put forward corresponding guiding suggestions, so as to break through the problem of personalized and differentiated teaching problems, to meet the talent training needs of the diversity, personalized and innovative.

\section{The Possible Combination of MOOC and College English Teaching}

With the premise that MOOC and college English teaching can be combined; it can believe that MOOC can be from the following two ways to be combined with college English curriculum system:

\section{MOOC After-Class Combined With Classroom Teaching to an Integrated Curriculum}

The teaching that is contained in the classroom keeps its pace with the MOOC learning and the two are interrelated with each other. In this kind of learning system, students should follow the contain that is taught by the teacher to select the MOOC after class, so as to keep the unity of learning online and offline. Under this system, the assessment of the course should be in coincidence with each other. In addition, the teachers play a dominant role in this model.

What is more, the communication function of language also decides that MOOC can make cooperation with the collage English teaching. The essence of language is making communication. The online MOOC provides the opportunity of making communication online for the students, which caters to the function of English teaching. Emphasis of the courses' interactivity is one of the important characteristics of MOOC. And at present, in China, some of the excellent course and video course which depend on the data technology have the problems that the interaction is not sufficient and the interface is not perfect, which hinders the perfect of the teaching effect. While, to some degree, MOOC makes a solution to this problem. MOOC can make a full consideration of the relationship between teacher and students and the relation between students. Then, MOOC can make the inflexible teaching mode more humanized by applying the course forum. Thus, the interaction and mutual evaluation of students can greatly promote the efficiency of the teacher's teaching and the students' learning, which in turn develop the function of MOOC to much extent.

\section{MOOC After-Class and Classroom English Teaching as Two Separate Part}

The teaching contain of MOOC and the classroom English teaching can be separated and their evaluation can also be made separately. Under this kind of system, the students can have more rights to choose learning contain, which do a help to cater to students' interests. For example, based on the media of language, the platform of "future learn" makes a collection of all kinds of learning recourses for the students to make a selection. Again, enough time is needed in the learning of language. But the teaching time in collages' English class is limited. Therefore, MOOC can make full use of the student's time after class.

"Open Education" is the basic idea of MOOC, which refers to that knowledge, should be shared unconditionally. Therefore, MOOC learning is without the limitation of region, country, area, and so on. It welcomes any person to join in the learning for free. 
Interest is the best teacher. As it is known, students' interests is closely connected with the contains of the courses. But as the number of students in one English class of a university is always big and every student's interest is not the same, the contains of the classroom-English-teaching class cannot satisfy every student. However, students can join the MOOC after class learning and select the learning contains by following their own willing, which can do much help in enhancing their progress in learning English.

\section{The Problems to Be Solved}

The construction of Course System is very complex. And based on the research of the above two types of connection, it believes that there are two main problems to be solved.

If the first connection type is chosen, the MOOC system must be developed by themselves which is a big task with a lot of works. What is more, how to make a combination of the online MOOC and offline MOOC in the curriculum evaluation of students is also a tricky problem to be solved. To solve all these problems above, there is not only a need of knowledge about language teaching, but also about the knowledge and problems of development and application of the engineering software.

If they apply the second model which the English classroom teaching and the MOOC learning after class are relative separation, there is a difficult problem of how the English teachers make effective guidance for the students' online learning. To make a conclusion, it clearly shows that the two models both have advantages and disadvantages, among which many problems remains to be further explored. Therefore, there is big exploration space to implement the MOOC in the college English teaching. Because lacking of proofs, the problems are not researched thoroughly in this paper; it should be treated specifically under specific conditions.

\section{Conclusion}

As a new curriculum, MOOC has immeasurable vitality and bright prospects. Under the informational age, the college English teaching can make full use of its advantages to make corresponding changes and reform. The combination of MOOC and the college English teaching owns the research value. This paper makes some analysis from the perspective of the possibility of the combination, the practical combination types, and the problems to be resolved of college English teaching and MOOC. I hope that this paper can serve as a guide for more researches and make a foundation for more valuable and specific researches in the future.

\section{References}

deWaard, I., Abajian, S., Gallagher, M. S., Hogu, R., Keski, N., Koutropoulos, A., \& Rodriguez, O. C. (2011). Using mLearning and MOOCs to understand chaos, emergence, and complexity in education. The International Review of Research in Open and Distance Learning, 12(7), 94-115.

Garrison, D. R., Anderson, T., \& Archer, W. (2000). Critical inquiry in a text-based environment: Computer Conferencing in higher education. The Internet and Higher Education, 2(2-3), 87-105.

George Siemens. (2005). Connectivism: A learning theory for the digital age. Retrieved from http://www.itdl.org/Journal/Jan_05/article01.htm

Kop, R. (2011). The challenges to connectivist learning on open online networks: Learning experiences during a massive open online course. The International Review of Research in Open and Distance Learning, 12(3), 19-38.

Masters, K. (2011). A brief guide to understanding MOOCs. The Internet Journal of Medical Education, 1(2), 2.

McAuley, A., Stewart, B., Siemens, G., \& Cormier, D. (2010). The MOOC model for digital practice. Retrieved from http://www.elearnspace.org/Articles/MOOC_Final.pdf 
Sadigh, D., Seshia, S. A., \& Gupta, M. (2012). Automating exercise generation: A step towards meeting the MOOC challenge for embedded systems. Retrieved from http://www.eecs.berkeley.edu/ dsadigh/WESE12.pdf

Siemens, G. (2005). Connectivism: A learning theory for the digital age. International Journal of Instructional Technology and Distance Learning, 2(1). 